\title{
The Politics of Social Pacts
}

\author{
Anke Hassel
}

\section{Article by an MPIfG researcher}

Anke Hassel: The Politics of Social Pacts. In: British Journal of Industrial Relations 41(4), 707-726 (2003). Wiley-Blackwell - SSH

The original publication is available at the publisher's web site: http://dx.doi.org/10.1046/j.1467-8543.2003.00295.x

\begin{abstract}
The paper develops an analytical framework for the politics of negotiated voluntary wage restraint in the context of social pacts. It argues that, in contrast to earlier political exchanges, tripartite negotiations on wage restraint under restrictive economic policies are not based on a political exchange whereby governments had to compensate trade unions for wage restraint. Rather, governments can threaten trade unions with tight monetary policy and trade unions can either engage in negotiated adjustment or suffer restrictions. Social pacts are therefore an instrument of adjustment by governments to a new economic environment, and not a tool of economic policy.
\end{abstract}

\section{Introduction}

Neo-corporatist approaches towards the relationship between governments and trade unions have found it difficult to account for the spread of tripartite negotiations between government, trade unions and employers in a number of European countries over the last twenty years (Fajertag and Pochet 2000; Hassel 2000; Regini 2000; Rhodes 1997, 2001; Schmitter and Grote 1997). There have been a number of reasons why these negotiations should not have taken place.

In the literature on the political economy of growth, strong trade unions were often portrayed as co-operating with left-wing governments in order to sustain full employment and induce investment (Cameron 1984; Lange and Garrett 1985; Alvarez, Garrett et al. 1991: 541). The mutually beneficial strategic interaction between left-wing governments and trade unions was based on the assumption that strong trade unions would be willing to exercise wage restraint only under the condition that the government ensured high investments and economic growth. Where unions were weak and labour markets decentralized, such as in the USA and the UK, national economic performance would be best provided by a conservative government, based on liberal market principles. In countries without such congruent regimes (strong labour/left government or weak labour/right government), either

Anke Hassel is at the Max Planck Institute for the Study of Societies, in Cologne. 
union militancy or inefficient 'adjustment policies' would dampen investment and growth (Scruggs 1999: 5). It follows that one should not expect an understanding between right-wing governments and (strong) trade unions on voluntary wage restraint, since the necessary trust in a policy of economic growth by the right wing government would not be available. A mutual understanding of the division of labour between governments and trade unions was seen as a major precondition for beneficial interaction of the two sides.

Other authors, who were also in the neo-corporatist approach, have argued that co-operation between social democratic governments and trade unions on wage restraint would be beneficial only in the context of a Keynesian economic policy (Scharpf 1991). According to Scharpf, in the context of a Keynesian demand policy, the government would be dependent on the willingness of trade unions to restrain wage claims in order to make expansive fiscal policies effective. If the government switched towards a monetarist strategy however, this dependency would lapse. In a monetarist context, excessive wage settlements are immediately punished by unemployment. Unemployment, unlike inflation, is experienced not as a collective evil but an individual risk, and trade unions will have to lower their wage claims accordingly (Scharpf 1991) Wage restraints will no longer be based on the encompassing structure of the trade union or the wage bargaining institutions. There should be no need for negotiated wage restraints under the condition of monetarism, as it should follow automatically.

Neo-corporatist theory itself has assumed that only certain kinds of trade union are capable of exercising wage restraint. Neo-corporatist theory has explained the interaction between governments and interest groups by pointing to the mutual gains of a closely knit division of labour between them. Public policy can try to ensure that interest groups articulate and position their interests in a more publicly desirable way by inviting them to influence public policies. Interest groups can restrain from upsetting government policies and thereby gain access to the formulation of other policies. Governments can offer organizational security to interest groups by granting representational monopolies or state funding. Centralized and monopolistic interest groups are more suited to neo-corporatist exchanges than pluralist ones. Over time, interdependence and mutual interpenetration of public policy and associational governance will increase and reproduce distinct patterns of policy-making (Schmitter 1974, 1977; Schmitter and Lehmbruch 1979; Streeck 1984).

With regard to wages, centralized trade union organizations were seen as the precondition to minimizing competition between trade unions and enabling trade union leadership to pursue a more inclusive and long-term strategy (Schmitter 1974; Streeck 1984). In economic approaches to the effects of labour market institutions on economic performance, wage restraint has been a function of encompassing trade unions, which had to internalize negative externalities of wage bargaining (Olson 1982; Calmfors and Driffil 1988). Fragmented and weakly organized trade unions should not be able to successfully negotiate voluntary wage restraint, but would face 
competitive wage pressure. In summary, the literature overwhelmingly argued that the relationship between labour market institutions, in particular the structure of trade union organizations, and the capacity of economic policymaking by governments is based on (a) the centralization of trade union and wage bargaining structures and (b) the capacity of governments to compensate trade unions for their co-operation.

However, throughout the 1980s and 1990s governments and trade unions have engaged in tripartite negotiations on wages and social policy (social pacts) in a number of European countries (see Table 1). These negotiations

TABLE 1

Co-operation between Social Partners and Government, 1980-1999

\begin{tabular}{|c|c|c|}
\hline Country & Year & Name \\
\hline \multicolumn{3}{|c|}{ Successful co-operation (Social Pact) } \\
\hline \multirow[t]{4}{*}{ Netherlands } & 1982 & $\begin{array}{l}\text { Agreement on 'generally binding recommendations on employment } \\
\text { policy issues' (Wassenaar) }\end{array}$ \\
\hline & 1990 & More Jobs for Ethnic Minorities \\
\hline & 1993 & A New Direction: Agenda for Collective Bargaining 1994 \\
\hline & 1997 & Agenda 2002 \\
\hline \multirow[t]{4}{*}{ Ireland } & 1987 & Programme for National Recovery \\
\hline & 1990 & Programme for Economic and Social Progress \\
\hline & 1994 & Programme for Competitiveness and Work \\
\hline & 1997 & Partnership 2000 for Inclusion, Employment and Competitiveness \\
\hline \multirow[t]{4}{*}{ Italy } & 1992 & $\begin{array}{l}\text { Tripartite Agreement on the Abolition of the Sliding Scale (Scala } \\
\text { Mobile) }\end{array}$ \\
\hline & 1993 & Ciampi Protocol: Agreement on Labour Costs of 23 July 1993 \\
\hline & 1996 & Employment Pact (Accordo per il Lavoro) \\
\hline & 1998 & Social Pact for Growth and Employment \\
\hline Denmark & 1987 & Agreement between the Social Partners \\
\hline \multirow[t]{3}{*}{ Finland } & 1991 & Stability Measures \\
\hline & 1995 & Social Pact \\
\hline & 1998 & Social Contract \\
\hline \multicolumn{3}{|c|}{ Attempted co-operation } \\
\hline Greece & 1997 & $\begin{array}{l}\text { Pact for Competitiveness (not signed by small and medium-sized } \\
\text { enterprises) }\end{array}$ \\
\hline \multirow[t]{2}{*}{ Spain } & 1994 & Toledo Pact (not signed by employers) \\
\hline & 1997 & Agreement between Social Partners \\
\hline \multirow[t]{2}{*}{ Portugal } & 1996 & $\begin{array}{l}\text { Short-term Tripartite Agreement (Acordo de Concertado Social de } \\
\text { Curto Prazo) (not signed by the CGTP) }\end{array}$ \\
\hline & 1997 & Strategic Social Pact (Acordo de Concertacao Estrategica) \\
\hline \multirow[t]{2}{*}{ Belgium } & 1993 & Global Plan (no agreement reached) \\
\hline & 1998 & $\begin{array}{l}\text { Cross-sectoral collective agreement (only achieved after legal } \\
\text { intervention) }\end{array}$ \\
\hline \multirow[t]{2}{*}{ Germany } & 1996 & $\begin{array}{l}\text { Alliance for Jobs and Prevention of Plant Closures (no agreement } \\
\text { reached) }\end{array}$ \\
\hline & 1998 & Alliance for Jobs, Training and Competitiveness (abandoned in 2002) \\
\hline Sweden & 1999 & Growth Pact (Allians för Tillväxt) (no agreement reached) \\
\hline France & 1995 & $\begin{array}{l}\text { Summit on reform of collective bargaining (led to further } \\
\text { decentralization of wage bargaining) }\end{array}$ \\
\hline
\end{tabular}

Country without any tripartite co-operation

Great Britain

Sources: Ferner and Hyman (1998); Hassel (1999, 2001); European Industrial Relations Review; Euro-Online (various issues). 
took place in an austere macroeconomic environment which restricted the capacity of governments to compensate. Moreover, not all of them had the institutional foundations for this policy pattern as predicted by neocorporatist theory. Among the countries with more successful co-operation, only the Netherlands, Denmark and Finland can be seen as traditionally corporatist. There were 'unlikely countries' (Baccaro 2001) - in particular Italy and Ireland - that should not have been able to negotiate successful tripartite agreements (Baccaro 2001). On the other hand, some traditionally corporatist countries - in particular Sweden and Germany - found it very difficult to find national agreements on adjusting wages to new economic circumstances. The degree of corporatism as portrayed in the literature has therefore not been a sufficient predictor for the capacity of governments and unions to seek and strike a new understanding about future wage bargaining developments.

This paper presents a framework for analysis of the role of tripartite negotiations on voluntary wage restraint. It has two central claims. First, it argues that tripartite negotiations are driven primarily by the aim of governments to ease the transition towards a tighter economic policy by negotiating with trade unions. Governments turn towards co-operation with trade unions if they perceive negotiated wage restraint as a strategy that can alleviate their problems more easily than would otherwise be the case. Trade unions, on the other hand, can make gains by tripartite agreements since their room for manoeuvre has decreased substantially with the adherence to a hard currency regime. The nature of the interaction between governments and trade unions has therefore changed. From a perspective of political exchange in which trade unions are compensated for wage restraint, which was the basis for corporatist interaction in the period up to the late 1970s, it has moved to a situation in which governments can threaten with tight monetary policy and trade unions can either engage in negotiated adjustment or suffer restrictions.

Second, the paper argues that under tight economic policy the interaction between governments and trade unions depends not on the ability of governments to compensate trade unions for wage restraint, but on their ability to display a commitment to restrictive monetary policies. This ability in turn is influenced by national political institutions that determine the dependence of governments on the social partners. Since restrictive economic policy carries costs if wage bargaining actors do not respond accordingly, governments have to be particularly insulated against the social partners, or they will be tempted to negotiate wage restraint.

This paper presents a theoretical understanding of the newly emerged negotiations between governments and social partners in western Europe. It draws on empirical evidence only to illustrate the general argument, and does not seek to prove the hypotheses empirically. The paper is divided in four parts. The next section presents the theoretical framework which combines recent arguments from the political economy literature with an older neocorporatist framework. Section 3 then shows how these changing economic conditions have altered the basis for political exchanges between governments 
and trade unions. Section 4 addresses the role of wage bargaining institutions. The last section draws out some implications following from the argument.

\section{The theoretical framework}

No government has ever considered tripartite agreements with trade unions and employers as an end in itself. Tripartite agreements were always a response by governments to existing problems. At the core, these problems were always economic - more precisely, macroeconomic - and the answer always involved a negotiated wage restraint. Today, as in the 1970s, governments negotiate wage restraint in order to alleviate their macroeconomic difficulties. At this very general level, nothing has changed between the 'old' forms of corporatism of the 1970s and the social pacts of the 1980s and 1990s.

However, the nature of the governments' macroeconomic problems is different today, and so is the nature of the solution to those problems. In the mid-1970s, the heyday of corporatist incomes policy in Western Europe, governments used these agreements primarily to fight the inflation triggered by the 1973 oil shock in order to ensure the maintenance of high-employment levels. This strategy was based on a fiscal and monetary autonomy of the government, which could employ both instruments to adjust its macroeconomic policies. Today's governments in western Europe face a major constraint which they had not faced during the 1970s, and which alters the problem that a negotiated incomes policy aims to address. This constraint is the near-universal move towards restrictive monetary policies in the member states of the European Union beginning with the shift of Bundesbank monetary policy in 1975. As the first of central banks in western Europe, the Bundesbank reacted with a sharp increase in interest rates towards the inflationary push after the oil shock. In the early 1980s the failure of Keynesian policies and the success of the German model had become clear. In Germany trade unions had accepted the tight monetary policy of the Bundesbank and had moderated their wage bargaining patterns accordingly. As a consequence, Germany could point to a relatively successful record in terms of unemployment and inflation. Increasingly, countries started to model their macroeconomic policies to the German example or to peg their currencies to the DM within the EMS which had basically the same effect (Andrews 1994; McNamara 1998).

Throughout the 1980s and 1990s, the remaining means of external adjustment were slowly eradicated. Devaluation of national currencies became progressively more difficult, since it tended to aggravate domestic problems by contributing to further inflationary pressures arising from the high level of intra-EU trade. Effective capital controls have become virtually abolished in recent years. Governments have therefore become unable to control the flow of money into and out of the domestic economy and need actively to attract 
foreign currency. Moreover, monetary policies, depreciation, capital controls and to some extent fiscal policies have all been surrendered to the European Monetary Union. The Maastricht Treaty, signed in 1991, signalled to domestic policy-makers that short-term adjustment would not be sufficient in the future.

The theoretical framework for explaining social pacts starts with this universal trend towards restrictive monetary regimes and the challenge it poses to wage bargaining institutions. It combines arguments about the interaction between monetary regimes and wage bargaining institutions and neocorporatist theorizing for understanding the interaction between governments and the social partners.

A substantial literature has argued that the organization of the labour market, and in particular the wage bargaining institutions, has an effect on wage bargaining behaviour and thereby on economic performance (Bruno and Sachs 1985; Calmfors and Driffil 1988; Soskice 1990; Calmfors 1993; Moene, Wallerstein et al. 1993; Flanagan 1999). Put very generally, specific properties of wage bargaining institutions provide incentives for wage bargaining actors to consider the effects of their wage settlements. The most important property of the bargaining system is the degree of centralization of decision-making on the wage demands of trade unions. In decentralized settings such as the UK, local bargaining units have few incentives to take into account the externalities of their behaviour for others. If a small bargaining unit negotiates a wage agreement, it tends to consider only the interests of its own members and to ignore the effects of the resulting price increase on other groups of workers. Other externalities can be the loss of employment and the consequences following from this (Flanagan 1999).

In contrast, where centralization is high, such as in Sweden, the leadership of a trade union has to make sure that the effect of a wage agreement is not harmful to its membership; it therefore internalizes negative externalities. The most important effect of centralization is therefore the moderation of wage demands. The leadership of trade unions in centralized settings is careful not to drive wage demands too high, since this might affect the employment situation of other groups of workers. Therefore, union leaderships tend not to employ their full bargaining potential; that is, they settle an agreement that is below what they had the potential to achieve. In this way, they tend to have a comparatively positive effect on performance. The exact relationship between wage bargaining institutions and economic performance has been discussed extensively, and many modifications can be found in the literature (see Iversen 1999; Traxler, Blaschke et al. 2001; Flanagan 1999). This argument assumes a linear negative relationship between the centralization of bargaining and the level of unemployment and real wages.

When it comes to the interaction of wage bargaining institutions and credible monetary policies, the situation is as follows. For wage bargaining actors, it is important to appreciate how the policy of the central bank affects the perceived costs of wage increases. It is only in centralized wage bargaining systems that the union leadership contemplates the trade-off between real 
wages and unemployment. In decentralized wage bargaining institutions the union will not react to monetary policy, for three main reasons (Hall and Franzese 1998). First, in decentralized bargaining situations local unions aim at protecting themselves from real-wage losses by seeking inflation increments on top of the real wage they desire, because they cannot anticipate the outcomes of other wage settlements. Second, in decentralized settings bargaining units do not take into account the effects of their settlements on other bargaining units. Third, none of the decentralized bargaining units will be held responsible for disinflationary policies by the monetary authorities if their settlements turn out to be inflationary.

In centralized bargaining arrangements, however, the trade union leadership will tend to assume a trade-off of unemployment against real wages. The policy of the central bank then becomes an important factor in wage bargaining, because it can affect the trade-off and deter high wage increases (Calmfors 2001: 333). If the unions anticipate that wage increases threatening the central bank's goal of price stability will trigger a more restrictive monetary policy, and therefore affect employment negatively, they will have an incentive to restrain wages that they would not have had otherwise. Centralized trade unions and bargaining institutions should therefore be particularly responsive to the monetary policy regime.

When wage bargaining is very centralized at the national level, such as in Sweden, this effect should decline, because highly centralized wage bargaining institutions have to internalize other negative externalities as well and an anticipated monetary policy reaction might not make much of a difference to their bargaining strategy anyway (Calmfors 2001: 334; Corricelli, Cukierman et al. 2000). Therefore, the strongest effect of interaction between monetary policy and wage bargaining institution should take place when bargaining is centralized at an intermediate level.

Empirical studies on the interaction of wage bargaining and monetary policy in OECD countries support these assumptions. Hall and Franzese (1998) found that higher central bank independence increases the level of unemployment when wage bargaining is decentralized. Cukierman and Lippi (1999) found that higher central bank independence reduces unemployment with intermediate centralization, but increases it with decentralization. This effect, however, decreases at higher levels of centralization. Bernhard Kittel (2000) reports that labour cost increases are inversely related to monetary restrictiveness, but positively related to higher levels of centralization of wage bargaining and union density. Iversen $(1998,1999)$ and Traxler, Blaschke et al. (2001) report a positive impact of an intermediate level of centralization when it interacts with restrictive monetary policy. Iversen (1999), however, uses a different argument to explain the lack of interaction of highly centralized wage bargaining systems. He argues that the responsiveness of highly centralized bargaining systems decreases because of the coalitions that highly centralized bargaining units have to engage in between the low paid and the high paid, which then leads to a higher degree of wage compression. Since the number of observations of different combinations of wage bargaining 
institutions and monetary policy is very small, the interaction effect, however, is not significant (Calmfors 2001: 334).

The theoretical and empirical political economy literature suggests that the effectiveness of monetary policy depends on the institutional arrangements of wage bargaining. Different institutions react differently to a change towards tighter monetary policy. The link between monetary policy and wage bargaining is the sharing and passing on of information about the credibility of tight monetary policies. It is only in co-ordinated or centralized wage bargaining systems - which constitute the majority of bargaining systems in Western Europe apart from the UK - that bargaining actors are receptive to this information and will take it into account when engaging in wage bargaining.

If wage bargaining institutions are relevant for conveying the credibility of monetary authorities and the likely impact of a tight monetary response to wage bargaining actors, the same argument can be made for the role of the government in wage negotiations. If high levels of credibility of monetary restrictiveness work best where bargaining actors are responsive towards the effects of their wage settlement on economic performance, governments still have an incentive to influence trade unions towards voluntary wage restraint. If wage bargaining institutions cannot adjust the wage expectations of workers to the economic situation, but trade unions and employers are nevertheless important bargaining actors on the labour market, governments might be tempted to increase the effectiveness of their disinflationary policies and ease the frictions between the expectations of workers and economic reality by negotiating with the social partners directly.

The capacity of governments to negotiate with trade unions over wages varies, depending on the organization of the labour market. In decentralized wage bargaining systems such as the USA and UK, the capability of governments to influence wage bargaining behaviour meaningfully is restricted. Local bargaining units may not be impressed by the government's efforts and may be unable to overcome their local competition. Governments may choose to deregulate the labour market further rather than seek interventionist solutions. In highly centralized bargaining arrangements such as in Sweden, bargaining units might not be sufficiently responsive to changes in the economic environment. Therefore, governments will be most likely to seek negotiations with trade unions on wage bargaining where bargaining units are sufficiently organized but not entirely responsive to tight monetary policies.

The argument here is similar to those made about the importance of wage bargaining institutions under credible conservative monetary authorities by Streeck (1994), Hall and Franzese (1998), Iversen (1999) and Traxler, Blaschke et al. (2001): namely, that the credibility of monetary policies needs institutional mechanisms to convey collective expectations to wage bargaining units. Centralized wage bargaining institutions can be the conveyors that internalize the effects of a credible conservative monetary institution and thereby dampen the negative real effects of disinflation. Another mechanism can be the intervention by governments to persuade wage bargaining actors 
to settle for lower wage claims, in order to pre-empt these expected negative effects. Government intervention can thus try to avoid the potential negative impact of disinflationary policies on the real economy by closing the gap between the wage expectations of workers and the expected restrictive monetary policies of the monetary authorities.

\section{Corporatism and the changing nature of the political exchange}

The political relationship between trade unions and governments has been described predominantly by the notion of political exchange (Pizzorno 1978). Political exchanges were based on the conversion of industrial into political power, in which trade unions could trade wage restraint for a wide variety of concessions from governments, such as industrial, regional and educational policy programmes, thereby wielding extensive power over public policy (Headey 1970; Lehmbruch 1984; Schmitter 1977; Korpi 1983). The concept assumed the existence of centralized unions commanding strong bargaining power, which could extract concessions from governments in exchange for moderate wage settlements. It assumed economic situations where the outcomes of collective bargaining were decisive for macroeconomic performance, especially with respect to monetary stability and employment, and where the political survival of the government depends on delivering low inflation and continued economic growth (Streeck and Hassel 2003).

During the 1970s, left-wing governments such as the Swedish Social Democrats committed themselves to high spending in order to maintain employment levels on the condition that trade unions exerted wage restraint. Not only was this policy seen as viable, but it was also regarded by some observers as superior in terms of economic growth (Cameron 1984; Lange and Garrett 1985).

The onset of tight monetary policy in the 1980 s, however, changed the nature of the exchange on wages between the government and trade unions. Since the turnaround in economic policy by the French government in 1983, public spending commitments have been discredited as economic policy and there has been no 'labour-friendly' demand strategy presented for resolving the crisis. In contrast to the assumptions of the Keynesian version of an incomes policy, there was no overall political-economic management strategy with which governments intended to tackle the crisis, but an incremental adjustment to external constraints. In other words, contrary to the ideas of economic management that assumed that a co-ordinated policy mix of fiscal and monetary policy could be employed to foster employment and growth, the switch towards restrictive monetary policies did not entail the notion of a strategy or an active role of policy-makers for macroeconomic performance. Moreover, governments have a deliberate choice between negotiating an incomes policy, or letting a restrictive monetarist policy take its course and reduce wage pressures even at the cost of high unemployment. During the exchanges of the 1970s monetary policy was an underdeveloped tool, but in 
the 1980s and 1990s this was no longer the case. No wage bargaining actor could claim unfamiliarity with the new policies, and trade unions were, in principle, well aware of the fact that the room for real wage increases was now tightly constrained by hard currency policies.

Negotiated wage restraint in the context of tight monetary policy was not based on an economic policy in which the pay-offs were clearly defined. Also, since the early 1980s western European governments had learned to understand the monetarist alternative for controlling wage pressure. Rather than depending on union approaches in wage bargaining, governments could turn to other instruments if wages got out of control. In a number of countries, such as France and Italy, importing the tight monetary policy by the Bundesbank was a major motivation for signing up for the European Monetary System (EMS). However, monetarist adjustment without the co-operation of trade unions could carry high costs in terms of employment if trade unions were not responsive to monetarist policies (Scharpf 1991). Restrictive monetary policies combined with aggressive wage bargaining could lead to exceptionally high increases in unemployment, as could be seen in the UK in the early 1980s. High and/or rising unemployment was not only politically unpopular, but also fiscally expensive. In this regard, the preferences of governments are distinct from the preferences of central banks, which did not have to care about growth and employment as governments did.

While governments forced themselves, by participating in European Monetary Union, to employ restrictive monetary policies in order to comply with the requirements of international capital markets, they had to ensure that the costs of these restrictive policies remained low. It was precisely the conflict between hard currency policies and their effects on the labour market that governments faced during the 1980s and 1990s. Their concern for employment effects gave rise to attempts to negotiate wages with trade unions in order to pre-empt damaging labour markets effects. As Fritz Scharpf had anticipated, under tight monetarist conditions governments were not dependent on trade unions to implement their economic policy; but they still had the chance to avoid negative effects if trade unions co-operated with their austere economic policy by restraining wages.

While governments had a choice on how to approach wage bargaining, trade unions had to face the fact that the pressures increased either way. They could either commit themselves to voluntary restraint, or face the consequences of higher unemployment if they did not. Since there was no longer a Keynesian scenario in which inflationary wage pressures could be accommodated by monetary or fiscal policy, the scope for wage increases had diminished. Higher employment losses would eventually drive wage increases down. If unions opted for a negotiated incomes policy, they could at least try to bargain over a price for wage restraint. If they did not, they had to face employment effects that - at least in the case of the UK - threatened to undermine their position on the labour market.

From the trade unions' perspective, the crucial question remained the extent to which the government or the central bank would actually punish 
wage bargainers for excessive wage agreements. If the government had a very clear line on tight monetary and fiscal policy - backed by independent central banks or tight exchange rate commitments - trade unions had to expect that wage bargaining would have an impact on employment. If, however, welfare provisions in the form of unemployment programmes and early retirement schemes could take care of the unemployed, the impact was likely to be less severe. The extent of trade union vulnerability to the effects of high-wage settlements was influenced by the strictness of macroeconomic policy and the provision of welfare.

So far, the argument is that there were good reasons to enter political exchanges, but these political exchanges took place under new conditions. In the past, political exchanges were based on the capacity of governments to compensate trade unions for wage restraint. Under monetarist conditions these exchanges are based on the capacity of governments to point out the consequences of excessive wage settlements to trade unions. Therefore the politics of the new incomes policy under tight monetary control often depended on the resolve of the government to credibly display its commitment to a non-accommodating monetary policy. As the costs of non-adjustment shifted towards the trade unions, the potential benefits thereby shrank.

Second, it also depended on the willingness of the government to accommodate increased unemployment. In the past, not only had politically dependent central banks accommodated inflationary wage settlements, but fiscal and social policies had absorbed some of the negative effects of wage increases. Expansive fiscal policies counteracted the negative impact of tight monetary policy when employed for disinflation and welfare programmes, and employment preservation schemes protected the trade unions and their members from the hardship of the market. The disciplinary force that stemmed from a tight monetary policy vis-à-vis the trade unions was therefore contingent on the position of the government vis-à-vis other policy fields and independent of monetary policy itself. Wider government policies were therefore an important contextual factor for the effectiveness of monetary policy. If governments were willing to accommodate the negative effects of a tight monetary policy rather than pass them on to the labour market, trade unions would not be affected in their bargaining strategies. If, however, governments were prepared to pass the effects on, and did not accommodate further pressures by means of social policies, trade unions could eventually be expected to adjust to the new situation. Governments were expected to be more likely to intervene in wage bargaining when they took an accommodating stance than otherwise. In other words, the more clearly the government could display its willingness not to accommodate high-wage settlements - either in terms of monetary policy or in terms of welfare policy - the smaller was the room for manoeuvre for tripartite negotiations.

The political exchanges that took place in the context of new social pacts therefore hinged on different factors. One of these factors relates to the uncertainty about the other actor's behaviour. It is important to remember that shifts in perceptions and strategies take time to disseminate. In the early $1980 \mathrm{~s}$ 
it was clear to most actors, governments and trade unions in western Europe that the Keynesian type of economic management was running out of steam. By tying their hands to EMS, governments anticipated that they would had to find ways of economic adjustment to a more austere hard currency model. Given the role model of Germany, elements of a new adjustment strategy were known in most western European countries. For example, in the mid1970s the French Prime Minister Raymond Barre developed the Barre plan, modelled on the German policy and consisting of the following four key policies: (i) control of the money supply, (ii) restrictive budgetary policies, (iii) wage restraint by social partners and (iv) stabilization of the franc (McNamara 1998: 131).

However, in the trade union organizations in many countries that participated in EMS, the implications for the rather different roles of government in the wage bargaining process were not so clear. In the early 1980s, only the German and Austrian trade unions had a reasonable expectation of the monetary response they had to expect when settling excessive wage settlements. Given their focus on exports of manufacturing goods, big manufacturers were particularly concerned about the impact of monetary policy on the exchange rate. In many other western European countries, however, the situation was far from clear. In some cases governments were still seeking external adjustment via devaluation or were pressuring other countries to refrain from competitive devaluation. In Italy, although the country was participating in the EMS, monetary adjustment did not start before 1988 and fiscal policies were tightened after 1992 (Walsh 1999). Until the early 1990s, the Italian trade unions had little to fear about the impact of their wage bargaining on employment. Devaluations were frequently employed in a number of countries. Relative to the value of the German mark, a number of countries devalued their currencies considerably during the 1980s even though they were committed to the EMS framework. For example, between 1979 and 1990 the mark increased its value against the Italian lira by as much as 63.5 per cent and against the French franc by 45.2 per cent.

In other cases trade unions could rely on further welfare buffering against unemployment, such as new pension schemes, early retirement or government subsidies for ailing companies. Governments aimed to tackle negative employment effects by reducing labour supply.

Each side was rather uncertain of the strategies being pursued by the other side. Only in Germany and Austria had a clear pattern of adjustment of wage bargaining to a restrictive monetary policy been established; however, in both cases large-scale employment and early retirement schemes took care of rises in unemployment. In most other cases, governments could not have a clear expectation as to how trade unions would react to a tighter monetary policy, although they had good reasons to believe that they would give in eventually. In the UK, when the government decided to switch towards a restrictive monetarist policy in 1979, there was no way of knowing how long it would take the trade unions to moderate their wage claims. In fact, it took the British government 13 years (until 1992) to bring nominal wage increases and 
inflation down to a German level, and during that time unemployment more than doubled (in the 1980s).

For trade unions the situation was doubly confusing: on the one hand, they could not be sure how firmly monetarist responses to wage bargaining would actually be implemented. On the other hand, they did not know to what extent welfare could still be expanded in order to compensate for the shrinking room for monetary accommodation.

Moreover, mutual uncertainty was based not only on the lack of information about policy issues and macroeconomic understanding on both sides, but also on the fact that both governments and trade unions, for a variety of reasons, were often inconsistent in their policies and were sometimes split on the issue themselves. Tripartite negotiations on wages therefore also served to facilitate the exchange of views and positions on the strictness of the economic policy framework and the severity of the external economic environment.

To complicate matters further, social and labour market policies, in particular early retirement, in many cases turned into a reform issue itself. The reform of welfare systems was also part of the public finance problem that governments tried to address with wage restraint. Therefore, a number of social pacts moved on from bargaining over wage restraint to include agreements over social policy reforms. In particular, in Italy the link between the agreements of 1993 (the Ciampi Protocol) and the pension reform in 1995 has been made explicitly (Regini and Regalia 1997; Baccaro 2000). But in the Netherlands also, authors have made a link between the Agreement of Wassenaar in 1987 and the Reform of the Disability scheme in 1989 (Visser and Hemerjick 1997; van Wijnbergen 1999; Ebbinghaus and Hassel 1999). In Spain the restructuring of the collective bargaining system in 1994 took place simultaneously with the first reform of labour market regulation.

This was partly because welfare reforms were driven by the need to reduce high public debt. Governments that were resolved on the issue of wage restraint were more often than not also determined to cut public expenditure. While influence over welfare reform was sometimes traded as the price for labour co-operation for wage restraint, it is sufficient to keep in mind that the opening up of negotiations on welfare reforms in principle introduces another bargaining variable for the interaction between governments and trade unions and thereby increases the uncertainty over the reaction of the other side on the issue of pay.

Negotiations between government and trade unions on voluntary wage restraints and welfare reform often took complex forms, because reform processes in the two policy fields followed rather different dynamics. Both underlying political-economic problems and the preference structures of actors regarding voluntary wage restraint and social policy reforms varied. There was no immediate reason why trade unions should provide legitimacy for welfare reform if they could resist it, since the negative consequences of non-cooperation were very long-term. Moreover, with regard to welfare retrenchment, there were many more distributional implications between the 
beneficiaries of the welfare state and those who were paying for it. As for the politics of welfare reform, a number of authors have pointed out that social policy reforms are dependent primarily on reputation, and they blame avoidance effects by governments, which tempts them to broaden the basis of political support for the reforms (Pierson 1996; Ross 1997: 175). Providing legitimacy for government reform is however a different process for trade unions than striking an agreement on voluntary wage restraint. From the government's point of view, these two processes can even be based on a tradeoff: a firm stand on restrictive monetary and fiscal policy might achieve wage restraint but prevent the co-operation of trade unions on welfare reform, as happened in the case of the German pension reform of 1996.

To conclude, the negotiations between governments and trade unions over wages are embedded in a wider context of monetary, fiscal and social policy. Governments started to constrain the room for wage bargaining by committing themselves to hard currency policy. However, during the first decade of the 1980s this commitment was not watertight in many countries. The room for wage bargaining was affected by social and fiscal policies. Generous welfare provisions buffered the impact of strict monetary policies. In this context, social pact negotiations were instruments by which governments could adjust trade unions' wage bargaining to the new economic context of a hard currency policy.

Governments were concerned to ensure that trade unions fully understood the externalities of their wage bargaining behaviour. Inflationary pressure was fought by monetary policy, but if tripartite negotiations could help the wage bargaining actors adjust to the new framework, it would lower the transition costs, notably increased unemployment, to the new status quo.

\section{The role of institutions and negotiations}

The new politics of state intervention therefore rested on an approach that conveyed a new policy paradigm to wage bargaining actors. The behaviour of bargainers did not depend on compensation offered in exchange for wage restraint, as implied in the traditional notion of political exchanges. It was based on the perception of a credible threat that the costs of inflationary wage bargaining would be born by the unions and their members in the form of higher unemployment and reduced social welfare programmes. The approach by the government concerned the limitation of the bargaining scope of the wage bargaining actors. Governments intervened in wage bargaining processes in order to change the rules of the game of the bargaining procedures themselves, by introducing a new economic framework.

This does not mean that there was no compensation for trade unions agreeing to voluntary wage restraint, but the compensation was not vital to the interaction between the governments and trade unions. While governments might concede tax reforms, delays in social policy retrenchment (Italy) or the installation of new committees on labour relations (Ireland), the capacity for 
compensation does not determine the approach by the government vis-à-vis wage bargaining.

The consequences of this were twofold. First, a new type of wage bargaining emerged, in which central agreements provide less statutory wage settlements, accomplished with local-level bargaining (Hassel 2002). Such agreements avoid many of the problems of political legitimacy that Shonfield (1965) raised in the mid-1960s, and which manifested themselves in many countries including France, Italy and Germany in the strike waves of the late 1960s (Soskice 1978). At the local level, management of export-sector firms were in control over labour costs and were able to limit excessive wage increases. At the national level, tripartite agreements on wages set the going rate for the economy as a whole. As they were under less immediate pressure to achieve wage moderation for fighting inflation per se, governments could use their influence more indirectly and thereby protect their authority and reduce their vulnerability to the turbulence often caused by their direct involvement in wage bargaining.

Second, negotiated wage restraint was not based on a bargaining relationship between governments and trade unions, but aimed to find a more a clearly defined division of labour in a framework of economic policy set by governments and of wage bargaining performed by the social partners. Wage bargaining institutions continued to mediate the effects of tight economic policy on the labour market, but by intervening in wage formation procedures governments now aimed to push wage bargainers into accepting responsibility for these effects and internalizing government economic policy choice as a fixed parameter in wage bargaining procedures.

The important consequence is that the role of wage bargaining institutions in the new interaction between government and trade unions has thereby changed. The nature of wage bargaining institutions and the degree of centralization of trade union organizations had dominated the entire literature on corporatism and political economy since Schmitter's article in 1974. On the other hand, Fritz Scharpf's argument that, under the condition of tight monetary policy, the labour market itself would take care of trade unions' wage demands had already internalized the argument of monetarist theory that wages would ultimately be disciplined by the market.

The new social pacts teach us that the role of wage bargaining institutions is now situated between the pressure of the labour market and the unions' capacity to internalize negative externalities. Adjustment of wage expectations can be delivered either by responsive (centralized) wage bargaining institutions, through internalizing negative externalities of high-wage settlements, or by negotiations between governments and trade unions. Governments used these negotiations in order to display their commitment to more restrictive monetary policies and thereby adjust the expectations of their national trade unions to the new hard currency regime. At the same time, local bargaining was disciplined by local market conditions.

This line of argument also explains why tripartite agreements are to be found in so-called 'unlikely countries' (Baccaro 2001) such as Ireland and 
Italy, which were not seen as corporatist during the 1970s and did not show the 'structural preconditions' for corporatist arrangements. These countries were facing serious challenges in committing themselves to the transition towards a hard currency regime, and were not very responsive wage bargainers. Trade unions played a considerable role on the labour market and were not easily sidelined or abandoned as partners. Tripartite wage agreements were seen and used by the government as instruments to remedy these problems and reconcile trade union participation in policy-making with a more restrictive economic environment.

\section{The politics of social pacts}

In contrast to the neo-corporatist incomes policy of the 1970s, the social pacts of the 1980s and 1990s were not based on a political exchange of wage restraint for policy concessions. The new social pacts were interactions between governments and trade unions in which governments set new tighter conditions for wage bargaining. The pacts were generated by the interaction of restrictive monetary policy and the nature of wage bargaining institutions in the individual countries. Governments could facilitate wage restraint, and had an incentive to do so in order to pre-empt harsher monetary policy. The behaviour of the governments was determined by (a) demands of a hard currency policy and (b) the behaviour of wage bargaining institutions when facing tighter economic policy. The new social pacts of the 1980s and 1990s thereby indicated that negotiated wage restraint by trade unions was prompted not by trust in the economic growth strategy of a leftwing government, but by the implications of a credible restrictive monetary and fiscal strategy.

The wider lesson that can be learned from the emergence of social pact negotiations during the 1980s and 1990s concerns the complex relationship between macroeconomic constraints and the governing role of institutions on the labour market. Neoclassic economic theory accounts for the level and persistence of unemployment with the lack of wage adjustments on the labour market. It assumes that wage levels will automatically adjust to the new expectation that a hard currency regime would impose. The social pact phenomenon of the 1980s and 1990s shows that this process does not occur automatically. It involves major adjustments in wage bargaining practices, most of which has to come about through the active role of the governments. The labour market remains a politically contested realm, where governments care about the effects of wage bargaining with regard to macroeconomic effects and the distribution of income. There is no such thing such an automatic market-driven response to economic adjustment in the context of the institution-rich labour markets of western European countries.

The institutional theories of the labour market and neo-corporatism, on the other hand, base their reasoning entirely on the degree of centralization 
of labour market institutions and trade unions. They assume that centralized trade unions are in control of local pay bargaining and therefore are in a position to enter into negotiations with governments. In fact, local pay bargaining in the exposed manufacturing sectors, which were usually the strongholds of trade union organization, is now controlled by conditions on the international product markets. National tripartite bargaining has been used to persuade those trade unions in the sheltered and public sectors to accept the logic of strict economic austerity. One should therefore expect that the heavy emphasis on centralized wage bargaining in institutional theories of neo-corporatism - based on the assumption of the internalization of negative externalities via hierarchical control - is no longer justified. While the economic problems of the labour market remain, the way in which labour markets and their institutions operate and interact with the economic environment has significantly changed.

Final version accepted 24 July 2003.

\section{References}

Alvarez, R. M. and Garrett, G. et al. (1991). 'Government partisanship, labor organization, and macroeconomic performance'. American Political Science Review, 85: $539-56$.

Andrews, D. M. (1994). 'Capital mobility and monetary adjustment in western Europe, 1973-1991'. Policy Science, 27: 425-55.

Baccaro, L. (2000). 'Centralized collective bargaining and the problem of "compliance": lessons from the Italian experience'. Industrial and Labor Relations Review, 53: 579-601.

(2001). 'The construction of "democratic" corporatism in Italy'. Paper presented at the Max Planck Institute for the Study of Societies, Cologne.

Bruno, M. and Sachs, J. D. (1985). Economics of Worldwide Stagflation. Cambridge, Mass.: Harvard University Press.

Calmfors, L. (1993). 'Centralisation of wage bargaining and macroeconomic performance: a survey'. OECD Economic Studies, 21(Winter): 161-91.

- (2001). 'Wages and wage-bargaining institutions in the EMU: a survey of the issues'. Empirica, 28: 325-51.

— and Driffil, J. (1988). 'Bargaining structure, corporatism and macroeconomic performance'. Economic Policy, 6: 14-47.

Cameron, D. R. (1984). 'Social democracy, corporatism, labour quiescence, and the representation of economic interest in advanced capitalist society'. In J. H. Goldthorpe (ed.), Order and Conflict in Contemporary Capitalism. Oxford: Oxford University Press, pp. 143-78.

Corricelli, F., Cukierman A. et al. (2000). Monetary Institutions, Monopolistic Competition, Unionized Labor Markets and Economic Performance, Report. University of Sienna.

Cukierman, A. and Lippi, F. (1999). 'Central bank independence, centralization of wage bargaining, inflation and unemployment: theory and some evidence'. European Economic Review, 43: 1395-1434. 
Ebbinghaus, B. and Hassel, A. (1999). 'The role of tripartite concertation in the reform of the welfare state'. Transfer, 1/2: 64-81.

Fajertag, G. and Pochet, P. (eds) (2000). Social Pacts in Europe: New Dynamics. Brussels: ETUI, OSE.

Ferner, A and Hyman, R. (eds) (1998). Changing Industrial Relations in Europe. Oxford: Basil Blackwell.

Flanagan, R. J. (1999). 'Macroeconomic performance and collective bargaining: an international perspective'. Journal of Economic Literature, 37: 1150-75.

Gros, D. and Thygesen, N. (1998). European Monetary Integration. Harlow: Addison Wesley Longman.

Hall, P. A. and Franzese, R. J. (1998). 'Mixed signals: central bank independence, coordinated wage bargaining, and European Monetary Union'. International Organization, 52: 505-35.

Hassel, A. (1999). 'The erosion of the German system of industrial relations'. British Journal of Industrial Relations, 37: 483-505.

— (2000). 'Bündnisse für Arbeit: Nationale Handlungsfähigkeit im europäischen Regimewettbewerb'. Politische Vierteljahresschrift, 3: 498-524.

(2001). 'The problem of political exchange in complex governance systems: the case of Germany's Alliance for Jobs'. European Journal of Industrial Relations, 7: 305-23.

- (2002). 'A new going rate? Co-ordinated wage bargaining in Europe'. In P. Pochet (ed.), Wage Policy in the Eurozone. Brussels/Bern/Berlin; Frankfurt/New/York/ Oxford/Vienna: PIE Lang, pp. 149-76.

Headey, B. W. (1970). 'Trade unions and national wages policies'. Journal of Politics, 32: 407-39.

Iversen, T. (1998). 'Wage bargaining, central bank independence, and the real effects of money'. International Organization, 52: 469-504.

(1999). Contested Economic Institutions: The Politics of Macroeconomics and Wage Bargaining in Advanced Democracies. Cambridge: Cambridge University Press.

Kittel, B. (2000). 'Trade union bargaining horizons in comparative perspective: the effects of encompassing organization, unemployment and the monetary regime of wage-pushfulness'. European Journal of Industrial Relations, 6: 181-202.

Korpi, W. (1983). The Democratic Class Struggle. London: Routledge \& Kegan Paul. Lange, P. and Garrett, G. (1985). 'The politics of growth: strategic interaction and economic performance, 1974-1980'. Journal of Politics 47: 792-827.

Lehmbruch, G. (1984). 'Concertation and the structure of corporatist networks'. In J. H. Goldthorpe (ed.), Order and Conflict in Contemporary Capitalism. Oxford: Clarendon Press, pp. 60-80.

McNamara, K. R. (1998). The Currency of Ideas: Monetary Politics in the European Union. Ithaca, NY: Cornell University Press.

Moene, K. O., Wallerstein, M. et al. (1993). 'Bargaining structure and economic performance'. In R. J. Flanagan, K. O. Moene and M. Wallerstein (eds), Trade Union Behaviour, Pay Bargaining, and Economic Performance. Oxford: Clarendon Press: 63-131.

Olson, M. (1982). The Rise and Decline of Nations: Economic Growth, Stagflation and Social Rigidities. New Haven, Conn.: Yale University Press.

Pierson, P. (1996). 'The new politics of the welfare state'. World Politics, 48 (January): 143-79. 
Pizzorno, A. (1978). 'Political exchange and collective identity in industrial conflict'. In C. C. A. Pizzorno (ed.), The Resurgence of Class Conflict in Western Societies since 1968. London: Macmillan, pp. 277-98

Regini, M. (2000). 'Between deregulation and social pacts: the responses of European economies to globalization'. Politics \& Society, 28 (1): 5-33.

and Regalia, I. (1997). 'Employers, unions and the state: the resurgence of concertation in Italy?' West European Politics, 20 (1): 210-30.

Rhodes, M. (1997). 'Globalization, labour markets and welfare states: a future of "competitive corporatism"'? EUI Working Paper RSC no. 97/36, European University Institute, Florence.

- (2001). 'The political economy of social pacts: competitive corporatism and European welfare reform'. In P. Pierson (ed.), The New Politics of the Welfare State. Oxford: Oxford University Press.

Ross, F. (1997). 'Cutting public expenditures in advanced industrial democracies: the importance of avoiding blame'. Governance, 10: 175-200.

Scharpf, F. W. (1991). Crisis and Choice in European Social Democracy. Ithaca, NY: Cornell University Press.

Schmitter, P. C. (1974). 'Still the century of corporatism?' Review of Politics, 36: 85-131.

(1977). 'Modes of interest intermediation and models of societal change in western Europe'. Comparative Political Studies, 10: 7-38.

and Grote, J. R. (1997). 'Der korporatistische Sysiphus: Vergangenheit, Gegenwart und Zukunft'. Politische Vierteljahresschrift, 38: 530-54.

— and Lehmbruch, G. (eds) (1979). Trends towards Corporatist Intermediation. Beverly Hills, Cal.: Sage.

Scruggs, L. (1999). 'The politics of growth revisited'. Paper prepared for the GAAC Summer Institute on Institutions and Economic Performance in Advanced Economies since 1945, CASBS, Palo Alto, Cal., 20-31 July.

Shonfield, A. (1965). Modern Capitalism: The Changing Balance of Public and Private Power. Oxford: Oxford University Press.

Soskice, D. (1978). 'Strike waves and wage explosions, 1968-1970: an economic interpretation'. In C. Crouch and A. Pizzorno (eds), The Resurgence of Class Conflict in Western Europe since 1968. New York: Holmes \& Meyer, pp. 221-46.

-(1990). 'Wage determination: the changing role of institutions in advanced industrialized countries'. Oxford Review of Economic Policy, 6(4): 36-61.

Streeck, W. (1984). 'Neo-corporatist industrial relations and the economic crisis in West Germany'. In J. Goldthorpe (ed.), Order and Conflict in Contemporary Capitalism: Studies in the Political Economy of Western European Nations. Oxford: Clarendon Press, pp. 291-314.

(1994). 'Pay restraint without incomes policy: institutionalized monetarism and industrial unionism in Germany'. In R. Dore, R. Boyer and Z. Mars (eds), The Return to Incomes Policy. London/New York: Pinter, pp. 117-40.

and Hassel, A. (2003). 'Trade unions and the political process'. In J. T. Addison and C. Schnabel (eds), International Handbook of Trade Unions. London: Edward Elgar.

Traxler, F., Blaschke, S. et al. (2001). National Labor Relations in Internationalized Markets: A Comparative Study of Institutions, Change, and Performance. Oxford: Oxford University Press.

van Wijnbergen, C. (1999). 'The politics of reforms: battling unemployment in Germany and the Netherlands'. Paper prepared for presentation at the 57th Annual Meeting of the Midwest Political Science Association, Chicago. 
Visser, J. and Hemerjick, A. (1997). 'A Dutch Miracle': Job Growth, Welfare Reform and Corporatism in the Netherlands. Amsterdam: Amsterdam University Press.

Walsh, J. I. (1999). 'Political bases of macroeconomic adjustment: evidence from the Italian experience'. Journal of European Public Policy, 6(1): 66-84. 